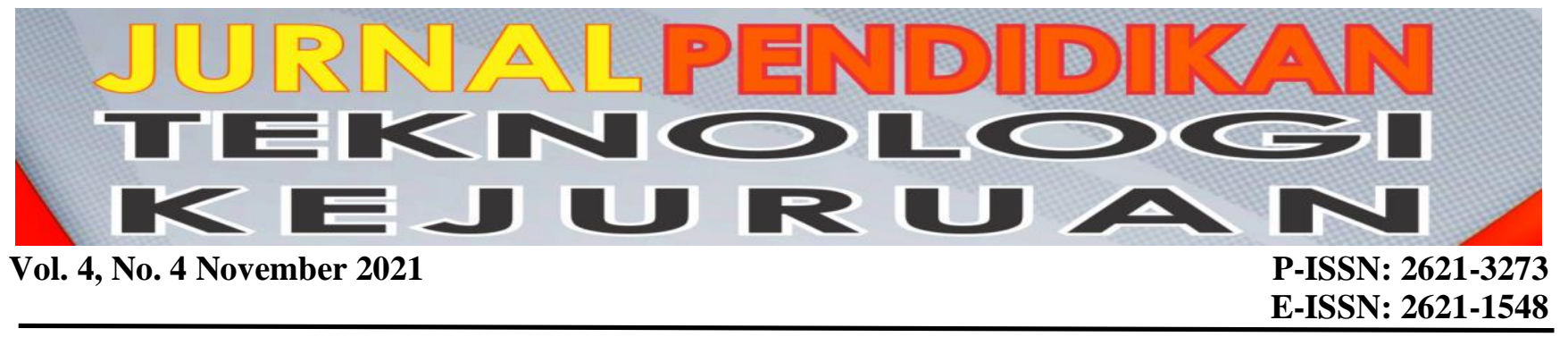

\title{
Efforts to Improve Problem Solving Skills and Critical Thinking Skills Through Problem-Based Integrated Computer Assisted Instruction (CAI) in Vocational Education
}

\author{
Rizky Ema Wulansari ${ }^{1 *}$, Rahmat Azis Nabawi ${ }^{2}$ \\ ${ }^{12}$ Mechanical Engineering, Faculty of Engineering, Universitas Negeri Padang \\ *Corresponding author, e-mail: rizkyema@ft.unp.ac.id
}

\begin{abstract}
Based on research conducted by PISA, the ability to solve problems and think critically of Indonesian students is still below the average score set by PISA. The score obtained by Indonesia is below the International Score Average set by the OECD, which is 500. Problem-based learning is one of the learning models recommended through the Ministry of Education and Culture to be applied in improving these abilities. However, the lack of problem-based learning that has been applied so far is the lack of use of media that can be used as support in learning activities, resulting in inconsistencies in the impact of problem-based learning in improving student skills. The importance of these skills for students to have in this era of the industrial revolution 4.0, makes educators have to be more creative and innovative in implementing learning. Therefore, this study aims at seeing efforts to improve problem-solving skills and critical thinking skills through problem based integrated computer-assisted instruction (CAI). This study used a quasi-experimental pre-test and post-test control group design. The population in this study were undergraduate students of Mechanical Engineering Education, Padang State University. The instrument used in this research is a questionnaire which is used to see students' problem solving and critical thinking skills. The data analysis technique in this study is in accordance with the research hypothesis, where research hypotheses 1 and 2 use independent sample t-test and research hypothesis 3 uses MANCOVA. The research covered by his study is in line with higher education's continuing search for effective SCL approaches. Based on the research findings, ProblemBased Integrated Computer Assisted Instruction (CAI) was proven effective in improving problem solving skills, as well as improving students' critical thinking skills. The drawback of this study is that there are several variables (soft skill, hard skill and etc) that have not been studied in the study, it is hoped that further research can investigate other variables related to higher order thinking skills.
\end{abstract}

Keyword: Problem Solving Skill; Critical Thinking Skills; Computer Assisted Instruction (CAI); Problem-Based

\section{INTRODUCTION}

The changing world has entered the era of the industrial revolution 4.0 or the 4 th world industrial revolution, where information technology has become the basis of everyday human life. This era has also influenced several human activities, including in the fields of science and technology and education (Lee et al., 2014). Universities must anticipate rapid technological developments as happened in the era of the industrial revolution 4.0. Curriculum and educational methods must be in accordance with industrial developments that occur (Jaschke, 2015; Erol et al., 2016). The challenges and responsibilities of Vocational Education and Education in particular are very important, because they must be able to produce graduates who have skills that are in accordance with the needs of the industrial revolution 4.0 (Lee et al., 2014; di Gropello et al., 2011).

According to di Gropello et al. (2011) the skills that must be possessed by vocational graduates in order to compete in this era of the industrial revolution 4.0 are thinking skills. Thinking skills are the most important skills to be developed, where di Gropello et al. (2011) also explains in his research that critical thinking skills and problem-solving skills are the first order of the types of thinking skills needed in this era. So that vocational education has an obligation to develop these skills in students, because thinking skills are one of the life skills that must be developed through the educational process (Depdiknas, 2002). 
However, in reality the results of the PISA test explain that the problem-solving ability of students in Indonesia is lacking. The score obtained by Indonesia is below the International Score Average set by the OECD, which is 500. Based on the results of PISA 2012, Indonesia is ranked 64th out of 65 participating countries, one level above Peru (OECD, 2013). Referring to the results of a survey conducted by the Martin Prosperity Institute, Indonesia is ranked 115th out of 139 countries (Peter, 2012). This explains that the critical thinking level of students in Indonesia compared to other countries is also relatively low. This can result in vocational graduates not being able to compete in this era of the industrial revolution 4.0. Many media, research methods and models have been applied to improve these skills, one of which is problem-based learning. In recent years, research has highlighted the effectiveness of problem-based learning of learning target competencies, such as problem-solving skills (Foster et al., 2017), creative thinking skills (Foster et al., 2017) and critical thinking skills (Ulger, 2018). The disadvantage of problem-based learning that has been applied so far is the lack of use of media that can be used as support in learning activities, resulting in inconsistencies in the impact of problem-based learning in improving student skills.

Therefore, the researchers tried to apply Computer Assisted Instruction (CAI) Integrated Problem-Based on undergraduate students of Mechanical Engineering Education in the Education media course. According to research conducted by Nuha (2016), problem orientation assisted by computerbased learning media can make students' understanding better. Therefore, researchers want to conduct research on efforts to improve problem solving skills and critical thinking skills through problem-based integrated computer assisted instruction (CAI) in higher education. Thus, the purpose of this research is to see efforts to improve problem solving skills and critical thinking skills through problem based integrated computer assisted instruction (CAI).

\section{A. Research Type}

This study uses experimental pre-test and post-test control group designs. According to Rubin and Babbie (Rubin \& Babbie, 2010), the pretest and posttest were perfectly designed to show the effectiveness of the media and the model used. It is used primarily to accurately describe causal relationships between variables, when groups are randomized, and one group is given treatment (Rubin \& Babbie, 2010; Camphbell \& Stanley, 1963; Christensen, 2001).

\section{B. Population and Sample}

The population of this research is all students majoring in Mechanical Engineering. Random sample selection can be done with two levels (Black, 1999; Lohr, 2010). Randomization of the sample was carried out by selecting subjects from a homogeneous population. In this study, the first condition for randomization was chosen by the simple random sampling method (Black, 1999; Lohr, 2010). So, at this stage, two classes were randomly selected from the Mechanical Engineering department as the experimental group and the control group. Thus, the students who participated in this study were undergraduate students of mechanical engineering education. Two homogeneous groups were selected from the sample as the experimental group and the control group.

\section{Research Procedure}

Both groups were given a pretest one week before treatment. Then both groups were given treatment, the experimental group used Computer Assisted Instruction (CAI) Integrated Problem-Based, and the control group used the conventional method for ten weeks. Then, the posttest was given at week 11 using the same instrument as the pretest.

\section{Research Instruments}

The instrument of problem-solving skills in this study is the Problem-Solving Inventory (PSI) (Heppner, 1988). PSI was chosen because the instrument is used to measure problem solving skills because PSI has used more than 100 investigations and has been called one of the most widely used instruments. The critical thinking skill instrument is an assessment rubric from the Association of American Colleges and Universities.

\section{E. Data Analysis Technique}

Research hypotheses 1 and 2 will be tested using independent sample t-test, where hypotheses 1 and 2 are as follows:

Hypothesis 1: There is no statistically significant difference in the mean score of the problem-solving ability test between the control group and the experimental group.

Hypothesis 2: There is no statistically significant difference in the average score of the critical thinking ability test between the control group and the experimental group.

While research hypothesis 3 will be tested using MANCOVA, where hypothesis 3 is as follows:

Hypothesis 3: There is no statistically significant difference in the average test scores of problemsolving and critical thinking skills between the control group and the experimental group 


\section{RESULT}

The mean and standard deviation of students' scores in the control and experimental groups on problem solving skills and critical thinking skills in relation to pre-test and post-test are presented in Table 1 .

Table 1. Mean and standard deviation

\begin{tabular}{lllcc}
\hline & \multicolumn{2}{c}{ Grouping } & mean & SD \\
\hline \multirow{2}{*}{ Problem } & Experimental & Pre-test score & 73.57 & 7.128 \\
solving & \multirow{2}{*}{ Control } & Post-test score & 88.23 & 10,858 \\
skills & & Pre-test score & 71.09 & 4.221 \\
& \multirow{2}{*}{ Experimental } & Post-test score & 72.71 & 11.004 \\
Critical & & Pre-test score & 82.6 & 5.055 \\
thinking & \multirow{2}{*}{ Control } & Post-test score & 89.6 & 9.008 \\
skills & & Pre-test score & 72.58 & 6.795 \\
& & Post-test score & 71.07 & 4.919 \\
\hline
\end{tabular}

Table 1 above describes the mean and standard deviation in the control class and the experimental class from the results of the pretest and posttest tests. It can be seen in the table that the mean of the experimental group on both variables is higher than the mean of the control group by $88.23(\mathrm{SD}=10.858)$ and $72.71(\mathrm{SD}=11.004)$ respectively. The post-test mean score on critical thinking skills in the experimental group exceeded the control group's average score by $89.6(\mathrm{SD}=9.008)$ and $71.07(\mathrm{SD}=$ 4.919).

Table 2. Normality Test

\begin{tabular}{lccc}
\hline No & Variable & p-value & description \\
\hline 1 & Problem Solving & 0.2 & Normal \\
2 & Critical Thinking & 0.182 & Normal \\
\hline
\end{tabular}

To find out whether the distribution of the data is normal or not, a normality test is carried out. This normality test uses the Kolmogorv Smirnof method with calculations carried out with the help of a special statistical program, namely SPSS version 16.0. If the data significance value is greater than $5 \%$ or 0.05 then the data can be said to be normally distributed. Based on the normality test on all variables large from 0.05 , namely for the X1 variable of $0.2>0.05$ and for the $\mathrm{X} 2$ variable of $0.182>0.05$. So, it can be concluded that the problem solving and critical thinking skills data in this study are normal.

Table 3. Homogeneity Test

\begin{tabular}{lcc}
\hline Variable & Levene's statistics & P value \\
\hline Problem solving test & 1.542 & .219 \\
Critical thinking test & .309 & .580 \\
\hline
\end{tabular}

Furthermore, homogeneity test on the results of research data, for this homogeneity test, the formula used is Levene's test. The function of Levene's test is to get a comparison of two groups of data on each variable in the study. The variance of different problem-solving skills $[\mathrm{p}>0.05$, $\mathrm{p}$-value $=0.219]$ and students' critical thinking skills $[\mathrm{p}>0.05, \mathrm{p}$ value $=0.580]$ resulted in insignificant results between class control and experiment. Therefore, it is very important to examine the relationship between the dependent variable (post-test) and covariates (pretest) [30]. The results of this test showed that the posttest data on each covariate of problem-solving skills and critical thinking skills was significantly ( $\mathrm{p}$ $>0.05)$. This shows that the assumption of homogeneity can be maintained.

\section{A. Hypothesis Test 1}

The first is to test the problem solving of the experimental group and the control group, this hypothesis testing is carried out using the independent sample t-test formula. This test serves to determine whether there is an integrated Problem-Based Computer Assisted Instruction (CAI) in improving student problem solving skills. The research hypothesis is as follows.

$\mathrm{HO}=$ There is no significant difference between the experimental group and the control group on the students' problem-solving ability test

$\mathrm{Ha}=$ There is a significant difference between the experimental group and the control group on the students' problem-solving ability test

The results of testing this hypothesis can be seen in Table 4 below.

Table 4. Results of the problem-solving t-test of the Experimental Group and Control Group

\begin{tabular}{cc}
\hline & Independent Sample t-test \\
\hline $\mathrm{T}$ & Exact Sig. [2*(1-tailed Sign.)] \\
\hline 2,567 & 0.005
\end{tabular}

Based on the results of the problem-solving t-test in Table 4, the significance results of the two groups if divided by 2 are 0.005 which means less than 0.05 ( $\operatorname{sig} 0.005<0.05$ ). So, it can be concluded that there is a significant difference between average value of problem-solving ability test control group with the experimental group. Average score of problemsolving ability test control group was 72.71 while average value of problem-solving ability test experimental group was 88.23 .

\section{B. Hypothesis Test 2}

The second thing to do is critical thinking tests the experimental group and the control group, this hypothesis testing was carried out using the independent sample t-test formula. This test serves to determine whether there is an effectiveness of the 
Problem-Based Integrated Computer Assisted Instruction (CAI) model in improving students' critical thinking skills. The research hypothesis is as follows.

$\mathrm{H} 0=$ There is no significant difference between the experimental group and the control group on the students' critical thinking ability test

$\mathrm{Ha}=$ There is a significant difference between the experimental group and the control group on the students' critical thinking ability test

The results of testing this hypothesis can be seen in Table 5 below

Table 5. Results of critical thinking t-test Experiment Group and Control Group

\begin{tabular}{cc}
\hline & Independent Sample t-test \\
\hline $\mathrm{T}$ & Exact Sig. [2*(1-tailed Sign. $)]$ \\
\hline 2,341 & 0.005
\end{tabular}

Based on the results of the $t$ test critical thinking on Table 5, the results obtained from the significance of the two groups if divided by 2 , it is 0.005 which means it is smaller than 0.05 ( $\operatorname{sig} 0.005<0.05$ ). So it can be concluded that there is a significant difference between critical thinking ability test average score control group with the experimental group. Average score of critical thinking ability test control group was 71.07 while critical thinking ability test average score experimental group is 89.6

\section{Hypothesis Test 3}

The third thing to do is critical thinking test and problem-solving experimental group and control group, this hypothesis was tested using the MANCOVA formula. This test serves to determine whether there is an effectiveness of the ProblemBased Integrated Computer Assisted Instruction (CAI) model in improving student problem solving and critical thinking skills. The research hypothesis is as follows.

$\mathrm{H} 0=$ There is no significant difference between the experimental group and the control group on the students' problem-solving and critical thinking skills tests

$\mathrm{Ha}=$ There is a significant difference between the experimental group and the control group on the students' problem-solving and critical thinking skills tests

The results of testing this hypothesis can be seen in Table 6 below.
Table 6. MANCOVA for problem solving skills and critical thinking skills scores

\begin{tabular}{|ll|r|r|r|r|r|r|}
\hline Source & $\begin{array}{l}\text { Dependent } \\
\text { Variable }\end{array}$ & $\begin{array}{c}\text { Sum of } \\
\text { Squares }\end{array}$ & df & $\begin{array}{c}\text { Mean } \\
\text { Square }\end{array}$ & \multicolumn{1}{c|}{ F } & $\begin{array}{c}\text { P } \\
\text { value }\end{array}$ & $\begin{array}{c}\text { Partial Eta } \\
\text { Squared }\end{array}$ \\
\hline Pre_PS & Post_CT & 16,817 & 1 & 16,817 & .258 & .614 & .005 \\
& Post_PB & 112,683 & 1 & 112,683 & .929 & .339 & .016 \\
\hline Pre_CT & Post_CT & 8,783 & 1 & 8,783 & .135 & .715 & .002 \\
& Post_PB & 56,659 & 1 & 56,659 & .467 & .497 & .008 \\
\hline Group & Post_CT & 1719.252 & 1 & 1719.252 & 26,354 & .000 & .316 \\
& Post_PB & 1930.905 & 1 & 1930.905 & 15,915 & .000 & .218 \\
\hline Error & Post_CT & 3718,502 & 57 & 65,237 & & & \\
& Post_PB & 6915,776 & 57 & 121.329 & & & \\
\hline Total & Post_CT & 625004,000 & 61 & & & & \\
& Post_PB & 404493,000 & 61 & & & & \\
\hline \multirow{2}{*}{ Corrected } & Post_CT & 7782,754 & 60 & & & & \\
\hline \multirow{2}{*}{ Total } & Post_PB & 10725.770 & 60 & & & & \\
\hline
\end{tabular}

Table 5 and 4 shows the $F$ value and $p$ value of each variable. The problem-solving test was that there was a statistically significant difference, $[F(1,57)=$ $15.915, \mathrm{p}<0.005]$. The null hypothesis is rejected; There is a significant difference between the experimental group and the control group on the students' problem-solving ability test. The result for critical thinking is that there is a statistically significant difference, $[\mathrm{F}(1,57)=26,354, \mathrm{p}<0.05]$. Therefore, the null hypothesis is rejected; There is a significant difference between the experimental group and the control group on the students' critical thinking ability test.

Table 6 shows the $F$ value and $p$ value of each variable. The problem-solving test was that there was a statistically significant difference, $[\mathrm{F}(1,57)=$ $15.915, \mathrm{p}<0.005]$. The null hypothesis is rejected; There is a significant difference between the experimental group and the control group on the students' problem-solving ability test. The result for critical thinking is that there is a statistically significant difference, $[\mathrm{F}(1,57)=26,354, \mathrm{p}<0.05]$. Therefore, the null hypothesis is rejected; There is a significant difference between the experimental group and the control group on the students' problemsolving and critical thinking skills tests.

\section{DISCUSSION}

Based on these results, it can be interpreted that students who are taught using Computer Assisted Instruction (CAI) Integrated Problem-Based get higher scores on the problem-solving test of students who are taught using TLA. Critical Thinking Skills of the PBL group students exceeded the Critical Thinking Skills of students in the TLA approach.

The results of this study reaffirm previous research, in which Problem-Based Integrated Computer Assisted Instruction (CAI) contributed to improving students' problem-solving skills, compared to TLA. 
In addition, Problem-Based Integrated Computer Assisted Instruction (CAI) improves students' problem-solving skills, in accordance with the theory highlighted in previous research (Woods et al., 2001; Wismath et al., 2015).

Several experimental studies of Integrated ProblemBased Computer Assisted Instruction (CAI) were previously carried out on problem-solving skills items, which resulted in positive findings in engineering (Donald R. Woods et al., 2002; Foster et al., 2017; Yalcin, 2006). In this study, students in Computer Assisted Instruction (CAI) Integrated Problem-Based had a higher capacity for problem solving skills, compared to students in TLA. Several previous studies conducted by various researchers showed similar results in information technology education (Budak et al., 2018; Jose, 2016; Özen, 2016; Chang et al., 2004). In addition, this finding is also in line with PBL's goal of instilling epistemological competence, as pointed out by SavinBaden (Savin-Baden, 2016).

After ten weeks of experimentation, the results showed that students who were taught using Integrated Problem-Based Computer Assisted Instruction (CAI) had better critical thinking skills than students who were taught using the TLA approach. Problem-Based Integrated Computer Assisted Instruction (CAI) improves students' critical thinking skills and enhances their knowledge acquisition. This study reaffirms the findings of previous studies, where Problem-Based Integrated Computer Assisted Instruction (CAI) contributes to improving students' critical thinking skills, covering a wide spectrum of educational levels and disciplines, such as high school and junior high school agricultural science (Burris, 2005; Anderson, 2007), technique (Donald R. Woods et al., 2002), and teaching education (Wismath et al., 2015).

According to the theory, mastery of knowledge is one of the prerequisites in developing students' higher cognitive abilities, especially critical thinking skills (Hmelo-Silver, 2004). Hmelo-Silver (2004) suggested that knowledge and working memory are operational and working in a social environment and attitudes promote students' critical thinking skills. Under Computer Assisted Instruction (CAI) Integrated Problem-Based, critical thinking skills are fostered through several processes such as discussions, brainstorming sessions, debate sessions, interaction, reflection, feedback, and mutual teaching (Hmelo-Silver, 2004)(Wee et al., 2003).

\section{CONCLUSION}

This study investigates the effectiveness of ProblemBased Integrated Computer Assisted Instruction (CAI) in Efforts to Develop Student Problem Solving Skills and Critical Thinking Skills. The research covered by his study is in line with higher education's continuing search for effective SCL approaches. In this study, Problem-Based Integrated Computer Assisted Instruction (CAI) was proven effective in improving problem solving skills, as well as improving students' critical thinking skills.

The findings of this study will contribute to existing knowledge, particularly in determining the effect of Problem-Based Integrated Computer Assisted Instruction (CAI) in Efforts to Improve Students' Problem-Solving Skills and Critical Thinking Skills compared to TLA. This study provides information on whether Problem-Based Integrated Computer Assisted Instruction (CAI) is feasible and can be applied in the context, sample, and population of mechanical engineering education students. Therefore, the curriculum development division can develop an effective curriculum based on the SCL approach using this method. The drawback of this study is that there are several variables (soft skill, hard skill and etc) that have not been studied in the study, it is hoped that further research can investigate other variables related to higher order thinking skills.

\section{ACKNOWLEDGEMENTS}

The authors would like to thank Lembaga Penelitian dan Pengabdian Masyarakat Universitas Negeri Padang for funding this work with a contract number: 697/UN35.13/LT/2021.

\section{REFERENCES}

Anderson, J. C. (2007). Effect of Problem Based Learning on Knowledge Acquisition, Knowledge Retention and Critical Thinking Ability of Agricultural Students in Urban Schools. University of Missouri.

Black, T. R. (1999). Doing Quantitative Research in the Social Sciences: An integrated approach to research design, measurement and statistic. Sage Publication.

Budak, E. Ç., Topal, A. D., \& Geçer, A. K. (2018). Developing the Scale of Problem-Solving Skills for Secondary School-Aged Deaf and Hard of Hearing Students. 3(1), 1-8. 
Burris, S. (2005). Effects of Problem Based Learning on Critical Thinking Ability and Content Knowledge of Secondary Agriculture. University of Missouri.

Camphbell, D. T., \& Stanley, J. C. (1963). Experimental and Quasi-Experimental Designs for Research. Houghton Mifflin Company.

Chang, E. C., D 'Zurilla, T. J., \& Sanna, L. J. (2004). Social problem solving: Theory research, and training. American Psychol- logical Association.

Christensen, L. B. (2001). Experimental Methodology. 8th ed. Allyn and Bacon.

Depdiknas. (2002). Kurikulum Berbasis Kompetensi SLTP Pedoman Umum. Direktorat Jenderal Pendidikan Dasar dan Menengah.

di Gropello, E., Kruse, A., \& Tandon, P. (2011). Skills for the Labor Market in Indonesia. https://doi.org/10.1596/978-0-8213-8614-9

Erol, S., Jäger, A., Hold, P., Ott, K., \& Sihn, W. (2016). Tangible Industry 4. 0: a scenariobased approach to learning for the future of production. Procedia CIRP, 54, 13-18.

Foster, N. L., Rawson, K. A., \& Dunlosky, J. (2017). Self-regulated learning of principle-based concepts: Do students prefer worked examples, faded examples, or problem solving? Learning and Instruction, 1-7.

Hmelo-Silver, C. E. (2004). Problem-based learning: What and how do students learn? Educational Psychology Review, 16(3), 235-266. https://doi.org/https://doi.org/10.1023/B:EDP R.0000034022.16470.f3

Jaschke, S. (2015). Mobile learning applications for technical vocational and engineering education: The use of competence snippets in laboratory courses and industry 4.0. Proceedings of 2014 International Conference on Interactive Collaborative Learning, ICL 2014, December, 605-608. https://doi.org/10.1109/ICL.2014.7017840

Jose, R. (2016). Research Papers Requisite for Honing the Problem-Solving Skill. 10(1).
Lee, J., Kao, H., \& Yang, S. (2014). Service innovation and smart analytics for Industry 4. 0 and big data environment. Procedia CIRP, $16,3-8$.

Lohr, S. L. (2010). Sampling: Design and Analysis, 2nd. Ed. Cengage Learning.

Nuha, M. A. (2016). Integrasi Teknologi Dalam Problem Based Learning Untuk Meningkatkan Kemampuan Pemecahan Masalah Siswa. Seminar Nasional Matematika X Universitas Negeri Semarang, 146-150.

OECD. (2013). PISA 2012 Results in Focus.

Özen, Y. (2016). Can I Solve the Problem? A Program Trail on Problem Solving Skill. 4(1), $1-10$.

https://doi.org/https://doi.org/10.12691/ajap-4$1-1$

Peter, E. E. (2012). Critical Thinking: Essence for Teachiing Mathematics and Mathematics Problem Solving Skill. African Journal of Mathematics and Computer Science Research, 5(3), 39-43.

Rubin, A., \& Babbie, E. (2010). Essential Research Methods for Social Work,2 . Ed. Cengage Learning.

Savin-Baden, M. (2016). The Impact of Transdisciplinary Threshold Concepts on Student Engagement in Problem-Based Learning: A Conceptual Synthesis. Interdisciplinary Journal of Problem-Based Learning, $\quad 10(2), \quad 9-13$. https://doi.org/https://doi.org/10.7771/15415015.1588

Ulger, K. (2018). The Effect of Problem-Based Learning on the Creative Thinking and Critical Thinking Disposition of Students in Visual Arts Education. Interdisciplinary Journal of Problem-Based Learning, 12(1), 3-6.

Wee, L. K.-N., Alexandria, M., Kek, Y.-C., \& Kelley, C. A. (2003). Transforming the Marketing Curriculum Using Problem-Based Learning: A Case Study. Journal of Marketing Education, 25(2),

$150-162$. https://doi.org/https://doi.org/10.1177/027347 5303254016 
Wismath, S., Orr, D., \& Mackay, B. (2015). Threshold Concepts in the Development of Problem-solving Skills. Teaching \& Learning Inquiry, 3(1), 1-8.

Woods, D. R., Kourti, T., Wood, P. E., Sheardown, H., Crowe, C. M., \& Dickson, J. M. (2001). Assessing problem-solving skills: Part I. The context for assessment. Chemical Engineering Education, 35(4), 300-307.

Woods, Donald R., Kourti, T., Wood, P. E., Sheardown, H., Crowe, C. M., \& Dickson, J. M. (2002). Assessing problem-solving skills part 2: Assessing the process of problem solving. Chemical Engineering Education, $36(1), 60-67$.

Yalcin, B. (2006). Short-term Effects of Problem based Learning curriculum on Students' Selfdirected Skills Development. Croat Med J., 47(491), 1-8. 